\title{
Firefly distribution and abundance on mangrove vegetation assemblages in Sepetang estuary, Peninsular Malaysia.
}

\begin{abstract}
Pteroptyx fireflies are commonly reported to congregate in large numbers in mangroves. Not much is known about the relationships between firefly distribution and abundance with specific mangrove vegetation assemblages. We conducted a study to investigate the vegetation assemblages that structure the distribution and abundance of Pteroptyx tener in Peninsular Malaysia. The distribution and abundance of fireflies were assessed along an $8 \mathrm{~km}$ stretch of mangroves in Sepetang estuary using visual assessment. Statistical analysis was carried out to test the correlation between length of display section and percentage cover of $P$. tener colonies and the relationship between percentage cover of fireflies with different vegetation assemblages. Five distinct vegetation assemblages were identified comprising different combination of four mangrove species. It was found that shorter display sections had higher percentage cover of P. tener colonies. In addition, vegetation assemblage which consisting of mainly Sonneratia caseolaris and Nypa fruticans was the most preferred type. The results of this study point to the necessity to consider not only a single mangrove species but the entire vegetation assemblage for firefly conservation.
\end{abstract}

Keyword: Fireflies; Pteroptyx tener; Sonneratia caseolaris; Mangrove vegetation assemblage; Sepetang estuary. 